\title{
Gospodynie domowe. Izolacja jako opresja
}

\author{
Dorothy Hobson \\ University of Wolverhampton \\ Przekład: Ewa Bodal i Nelly Strelau
}

(Tekst oryginalny pt. „Housewives. Isolation As Oppression” ukazał się w 2012 r. w Women Take Issue. Aspects of Women's Subordination. Women's Studies Group: 79-96, Routledge: Oxford ${ }^{39}$.)

Przekład zaakceptowano: czerwiec 2015; opublikowano: lato 2015.

\begin{abstract}
Abstrakt redakcyjny
Artykuł oparty jest na badaniach autorki nad kulturą młodych gospodyń domowych z klasy robotniczej, przebywających $\mathrm{w}$ domu z małymi dziećmi. W badaniach wykorzystano wywiady z tymi kobietami, skoncentrowane na ich roli jako gospodyń i matek oraz na ich rozumieniu tej roli względem doświadczeń z wykonywanej wcześniej pracy zarobkowej. Autorka, analizując subiektywne relacje badanych, wskazuje m.in. na ujawniające się w nich poczucie opresji.
\end{abstract}

Słowa kluczowe: kobiety; izolacja; opresja; kapitalizm; praca zarobkowa.

DH Czy myślisz kiedykolwiek o sobie, a jeśli tak, w jaki sposób byś się opisała?

AB Zawsze szukam czegoś lepszego . . . nie wiem, tak naprawdę . . . widzę się jako tę osobę, która musi zostać w domu ... (śmiech). Czasami jestem bardzo zadowolona, a czasami myślę, że „to niesprawiedliwe”, no wiesz. Nie mogę tak naprawdę myśleć o sobie.

Niniejszy artykuł oparty jest na badaniach, które obecnie prowadzę nad kulturą młodych gospodyń domowych z klasy robotniczej, przebywających $\mathrm{w}$ domu z małymi dziećmi ${ }^{40}$. Odbywają się one poprzez nagrywanie wywiadów w domach tych kobiet i dotyczą wielu aspektów ich osobistego doświad-

\footnotetext{
${ }^{39}$ Przekład publikowany za zgodą właścicieli praw do tekstu.

${ }^{40}$ Pierwotnie kontaktuję się z moimi rozmówczyniami w lokalnej „klinice środowiskowej”, gdzie pielęgniarka uprzejmie pozwala mi podejść do kobiet, gdy czekają na wizytę u lekarza. Wyjaśniam im moje badania, mówiąc, że jestem zainteresowana tym, jak kobiety doświadczają bycia żoną i matką. Pytam też, czy byłyby skłonne mi pomóc, pozwalając odwiedzić się w domu i zadać pytania o to, jak wygląda ich życie obecnie i jak wyglądało, zanim wyszły za mąż.
} 
czenia, zarówno z czasów poprzedzających ich małżeństwo, jak i w ich obecnej sytuacji ${ }^{41}$. W tekście koncentruję się na roli tych kobiet jako gospodyń domowych i matek, a także na tym, jak rozumieją one tę rolę w odniesieniu do swoich wcześniejszych doświadczeń podczas pracy zarobkowej. Skupiam się na odizolowaniu kobiet w sprywatyzowanej sferze domu, próbuję także przedstawić izolację jako jeden ze sposobów doświadczania opresji przez kobiety i umieścić to doświadczenie w strukturach kapitalizmu. Chociaż rozpoznaje się, że nie ma prostego sposobu „odczytania” relacji z subiektywnego doświadczenia, utrzymuję, że - jakkolwiek niebezpośrednio - wskazują one na miejsca sprzeczne strukturalnie. Uważam także, do czego przekonuje Sheila Rowbotham (1973), że subiektywne doświadczenia kobiet ujawniają „poczucie opresji”, i widziałabym tę opresję jako posiadającą podstawę materialną.

W trzecim artykule książki Housewives. Isolation As Oppression, in Women Take Issue. Aspects of Women's Subordination. Women's Studies Group [szerzej] rozważam centralną pozycję pracy kobiet w codziennej i pokoleniowej reprodukcji nosicieli siły roboczej, [natomiast] poniższą analizę opieram na stanowisku teoretycznym, które tam rozwijam.

Kapitał oferowany w zamian za siłę roboczą zostaje przeliczony na środki utrzymania, które muszą być skonsumowane w celu reprodukcji mięśni, nerwów, kości i mózgów istniejących pracowników, i w celu stworzenia nowych pracowników. W granicach tego zatem, co absolutnie koniecznie, indywidualna konsumpcja klasy robotniczej jest konwersją środków utrzymania oferowanych przez kapitał w zamian za siłę roboczą w świeżą siłę roboczą, którą kapitał potem może znów wykorzystywać. Jest to produkcja i reprodukcja najbardziej niezbędnego środka produkcji kapitalizmu: pracownika. Konsumpcja indywidualna robotnika, niezależnie, czy odbywa się w miejscu pracy czy poza nim, wewnątrz procesu roboczego czy poza nim, pozostaje aspektem produkcji i reprodukcji kapitału, tak samo jak czyszczenie maszyn, niezależnie, czy robi się to $\mathrm{w}$ trakcie procesu roboczego lub kiedy pozwalają na to przerwy w tym procesie. (Marks 1976: 717)

Marks zdawał sobie sprawę, że produkcja i reprodukcja robotnika jest niezbędna dla kapitału i chociaż odbywa się poza procesami samej pracy, pozostaje „częścią produkcji i reprodukcji kapitału”. W tym samym rozdziale dodaje: (Marks 1976: 718) „Utrzymanie i reprodukcja klasy robotniczej pozostaje

\footnotetext{
${ }^{41} \mathrm{Z}$ powodu braku miejsca nie skupiam się na wielu aspektach życia moich rozmówczyń, które uważam za istotne. Pozostałe obszary, które uwzględniam w wywiadach, obejmują: sytuację rodzinną i wykształcenie, sposoby spędzania czasu wolnego przed ślubem, podejście do prac domowych i szczegółowe omówienie rutyn związanych z pracami domowymi, sieci społecznościowe, aktualne sposoby spędzania czasu wolnego, rolę mediów w życiu kobiet, odczucia na temat ich obecnego życia i przyszłości. Najbardziej widoczne ominięcie to brak odwołań do form oporu, jakie mogłyby negocjować kobiety za pomocą choćby oporu seksualnego czy fantazji seksualnych, zwłaszcza poprzez swoje relacje z mediami (zob. przypis 43). Nie sądzę jednak, że te pominięte tematy zmieniłyby zasadniczą argumentację niniejszego artykułu (zob. przygotowywana praca magisterska).
} 
niezbędnym warunkiem reprodukcji kapitału. Kapitalista może jednak spokojnie zostawić [te czynności] popędowi samozachowawczemu i popędowi rozrodczemu robotnika”.

Marks pisze dalej, że (719) „Reprodukcja klasy robotniczej sugeruje jednocześnie transmisję i akumulację zdolności z pokolenia na pokolenie”.

To w obrębie tego kluczowego rejonu, który sytuuje się poza procesem pracy zawodowej, ulokowana jest nieodpłatna praca wykonywana przez kobiety. Praca, którą kobiety wykonują w tym procesie, jest „niewidzialna” z punktu widzenia kapitału, a ich opresja także pozostaje „niewidzialna” dla większości analiz procesu akumulacji kapitału - dlatego, że jest strukturalnie nieobecna, lub dlatego, „że jej nie widać”. Podobnie uważam, że transfer umiejętności niezbędnych dla reprodukcji pokoleniowej, odbywa się w rodzinie, zarówno zanim dzieci wkroczą w państwowy aparat edukacji, jak i później (Althusser 1971).

\section{Uwagi metodologiczne}

Metoda przeprowadzania wywiadów typu jeden-na-jeden wymaga komentarza. Zazwyczaj czuję pewnego rodzaju niepokój, kiedy po raz pierwszy przychodzę do czyjegoś domu w celu przeprowadzenia wywiadu, chociaż jestem bardziej nerwowa w klinice, gdzie wstępnie rozmawiam z kobietami. Jednakże sytuacja w domach nie jest nigdy tak napięta, jak mogłoby sugerować słowo „wywiad”, gdyż „scenografia” jest nieformalna. Zazwyczaj obecne są z nami małe dzieci albo niemowlęta, często bawiąc się głośno w pokoju lub domagając się uwagi, co eliminuje wszelkie skłonności do tego, by przeprowadzać wywiad bardziej formalnie. Najtrudniejsze okazuje się powstrzymywanie się przed komentarzem, który mógłby sugerować odpowiedzi, jakich kobiety udzielają na moje pytania. Kiedy jednak nagrywanie wywiadu dobiega końca, zazwyczaj rozmawiamy, a kobiety zadają pytania o moje życie i rodzinę. Pytania te często dotyczą tych obszarów, co do których miały one mieszane uczucia we własnych odpowiedziach. Na przykład pewna kobieta, która powiedziała podczas wywiadu, że nie lubi być mężatką, zapytała mnie, od jak dawna jestem w związku małżeńskim i czy to lubię. Kiedy odpowiedziałam, odparła: „Cóż, przypuszczam, że można się do tego z czasem przyzwyczaić, pewnie tak będzie ze mną”* (zob. Klucz do transkrypcji na końcu tekstu). De facto nieformalne rozmowy po wywiadzie często potwierdzają to, co zostało powiedziane w samym wywiadzie.

Nie można dokładnie określić, jak jestem postrzegana przez te kobiety, ale nie sądzę, by widziały mnie jako osobę bardzo odległą od nich samych. Może to częściowo wynikać z faktu, że muszę umawiać się na wywiady, kiedy mój syn jest w szkole, i wychodzić tak, żeby zdążyć go z niej odebrać. Mogą postrzegać moje życie jako bardziej „ekscytujące” niż ich własne, ale nie wydaje się, by uważały, że mam życie „idealne”. Jak powiedziała jedna z kobiet: „założę się, 
że nawet ty masz bardziej interesujące życie niż ja”.* Zdecydowanie zawsze interesują się moimi badaniami oraz tym, co inne kobiety myślą na temat swojego życia.

Metodologia i forma, z których korzystam, mogą sprawić, że poczucie izolacji ulegnie wzmocnieniu, co być może prowadzi do powstania uwrażliwionych interpretacji życia kobiet, które skupiają się bardziej na swoim poczuciu izolacji niż na innych aspektach. Nie sądzę, by unieważniało to jakiekolwiek z wyników; sądzę, że dzięki temu mój zasadniczy argument przedstawia się jeszcze bardziej wyraziście. Izolacja pozostaje. Kiedy wychodziłam po jednym z wywiadów, pewna kobieta powiedziała: „Założę się, że nikt ci nigdy nie odmawia, żebyś przyszła i przeprowadziła wywiad, to coś, na co czekałam i co naprawdę mi się podobało”.* Pierwsza część jej komentarza jest prawdą: nikt nigdy nie odmówił mi wywiadu.

Przedstawianie materiału nagranego na taśmę jest problematyczne, ponieważ wiele traci się przy przetwarzaniu języka mówionego w zapis. Szczególnym mankamentem jest niemożność odpowiedniego przedstawienia wagi intonacji i oddania znaczeń przekazywanych za pomocą komunikacji niewerbalnej. Nie proponuję, by analizować jej ważność, z wyjątkiem kluczowych momentów, kiedy pojawia się śmiech. Sheila Rowbotham (1969) komentuje śmiech dziewcząt następująco: „Dziewczęta śmieją się w chwilach tabu. To sposób zarówno podkreślenia czegoś ważnego, jak i uniknięcia jakiejś kwestii. Uniemożliwia krytykę i nie odkrywa kart”.

W niniejszym artykule obecność śmiechu traktuję jako ważny na poziomie teoretycznym element zrozumienia, czym jest kobieca opresja. Poniższe komentarze odnoszące się do śmiechu oparte są na analizie konkretnego fragmentu, ale takie podejście teoretyczne do śmiechu można zastosować do całej analizy. Kobieta śmieje się najpierw, mówiąc o pracach, które wykonywała przed ślubem. Jest świadoma tego, że podejmowała się wielu prac, lecz nie przyznaje ani razu, że to dlatego, że same prace były trudne do wytrzymania; sądzi, że wina leży po jej stronie. Drugi temat wywołujący śmiech to rozmowa o możliwości, by to kobieta chodziła do pracy, a nie jej mąż. Wskazuje to na rozpoznanie przez nią, że mowa jest o wymianie ról, którą uważa za temat „tabu”, [za coś] nie do pomyślenia, chyba że zuchwałość i „skandaliczność” tej sugestii zostanie zaznaczona, opanowana i na wpół zaprzeczona śmiechem. Kobieta jest świadoma, że tradycyjne podejście wymaga, by to mężczyzna pracował, a jej sugestia, że to ona chciałaby podjąć tę rolę, to przestrzeń, gdzie należy uniknąć dyskusji.

Kolejna rzecz na temat śmiechu odnosi się do cytatu na początku tego artykułu, pochodzącego z transkrypcji rozmowy z tą samą kobietą: „widzę się jako tę osobę, która musi zostać w domu . . . (śmiech)”. Tutaj rozpoznaje ona swoją opresję, ale akceptuje tę sytuację, chociaż sugeruje nie wprost, że uważa ją za niesprawiedliwą. Śmiech sprawia, że żadna z nas nie musi dyskutować dalej; 
stwierdzenie obowiązuje, ale śmiech je opanowuje. Pokazuje, że sprze-czność została rozpoznana, ale mimo wszystko pozwalamy jej obowiązywać.

Chciałabym rozwinąc to, co Sheila Rowbotham pisze o śmiechu, odnosząc się do własnego rozumienia ważności śmiechu w niniejszych wywiadach. W omawianych przed chwilą przykładach, jak i w innych odnotowanych $\mathrm{w}$ tym artykule śmiech pojawia się $\mathrm{w}$ momentach sprzeczności, kiedy możliwe są konkretne - choć mało prawdopodobne - alternatywy, lub kiedy ujawniają się miejsca sprzeczności. Jednakże śmiech określa także pole wzajemnego porozumienia pomiędzy mną a moimi rozmówczyniami. Nie ma potrzeby, by wyjaśniały, dlaczego się śmieją lub dlaczego w pewnych chwilach śmieję się z nimi, gdyż śmiech jest formą komunikacji niewerbalnej, którą rozumieją obie strony. „Działa” on na tle milczącej (obopólnej) wiedzy, zdroworozsądkowych przekonań na temat kobiet nieustannie przywoływanych w rozmowach; na ich podstawie wyrażane przekonania „mają sens”.

\section{Praca zarobkowa}

Doświadczenie pracy zarobkowej moich rozmówczyń pochodzi z tradycyjnych obszarów pracy, które zarówno pod względem klasy, jak i płci są swoiste dla dziewcząt $\mathrm{z}$ klasy robotniczej, kończących szkołę. Pracowały w sklepach, biurach, fabrykach i w najsłabiej płatnych zawodach sektora usług. W poniższych fragmentach kobiety opowiadają o pracach wykonywanych przez siebie przed ślubem. Chciałabym skupić się na dwóch aspektach tych wypowiedzi dotyczących pracy. Charakter wykonywanych prac jest oczywisty; w większości stanowią one przykłady nudnego, monotonnego wysiłku, natomiast młode kobiety narażone były na ryzyko zawodowe związane z taką pracą: traciły pracę i cierpiały na urazy z nią związane (na przykład na alergię na plastik). To, co czyniło pracę możliwą do wytrzymania, a nawet przyjemną, to towarzystwo innych osób - ludzi, z którymi można było rozmawiać. W wypowiedziach widać zatem świadomość, że wykonywana praca była nudna i że w miejscach pracy często wymieniano pracowników, nie ma jednak świadomości, że moje rozmówczynie i inne pracownice były wykorzystywane. Problemy postrzegane są jako osobiste niedociągnięcia. To, o czym się „,wspomina”, to wynagradzający kontakt z ludźmi, dzięki którym niemożliwa do zniesienia praca stawała się znośna.

\section{Anne}

DH Jaką pracę wykonywałaś, kiedy pracowałaś?

AB Każdą (śmiech). Zaczęłam w fabryce, nie, kiedy miałam piętnaście lat, pracowałam na część etatu, tylko w soboty, kiedy jeszcze byłam w szkole. Pracowałam tam około dwóch lat. 
DH Gdzie to było?

AB Woolworths. (śmiech) A potem rzuciłam tę pracę i pracowałam w fabryce, ale zwolnili mnie po pół roku.

DH Co robiłaś w fabryce?

AB Składałam adaptery. A potem poszłam do fabryki, gdzie robili sznurki, liny. Bardzo brudna robota. Po sześciu miesiącach odeszłam i pracowałam w Butlins. Jestem okropna, jeśli chodzi o pracę, możesz mi wierzyć. (śmiech)

DH Co robiłaś w Butlins?

$\mathrm{AB}$ [Miałam tam] dwie posady, najpierw w sklepie, a potem byłam kelnerką. Bycie kelnerką podobało mi się o wiele bardziej.

DH Czy podobały ci się posady, które miałaś?

AB Tak. Nie lubiłam tylko tej brudnej, jak mówiłam, tej, w której robili sznurki. To było dość, no wiesz, nudne, bardziej nudne niż wiele posad w fabryce, bo było za głośno, żeby rozmawiać. Nie przeszkadza mi praca nad czymś nudnym w fabryce, jeśli można rozmawiać z kimś obok. Ale . . w tamtym miejscu nie dało się tak naprawdę rozmawiać.

DH Czy miałaś wielu przyjaciół w pracy?

AB Tak.

DH Nie pracujesz teraz; czy chciałabyś iść do pracy?

AB Bardzo (śmiech). Dziś rano powiedziałam do Richarda: „Czy mogę ja iść do pracy, a ty zajmiesz się dzieckiem”? Bardzo bym chciała. Wiesz, gdyby nie to, że on [mąż] naprawdę nie zmieni mu pieluszek, to fakt, nie tknie ich, pozwoliłabym mu zostać w domu i poszłabym sama do pracy. Bo mogłabym łatwo znaleźć pracę, naprawdę, bo umiem obsługiwać prasę ręczną, prasę elektryczną i tym podobne prace, które, wiesz, ludzie szybko rzucają.

\section{Linda}

LW Zaczęłam od sklepu - Lewisa. Pracowałam tam pół roku, a potem odeszłam, bo godziny pracy były za długie. Przychodziłam do domu późno i nie mogłam już wyjść; a potem poszłam pracować w fabryce, która produkowała spryskiwacze ogrodowe. Stamtąd musiałam odejść, bo miałam alergię na plastik. A potem poszłam pracować w tym samym miejscu, gdzie moja mama, do fabryki, wiercić i frezować.

DH Tak, i podobało ci się to?

LW Tak, bardzo to lubiłam.

DH Czy to pracę lubiłaś, czy ... 
LW Lubiłam pracę, bo każdego dnia robiło się coś innego, i lubiłam ludzi, była tam fajna grupa ludzi.

\section{Betty}

BW Kiedy skończyłam szkołę, poszłam najpierw do pracy w sklepie w mieście, British Home Stories, i nie lubiłam tego za bardzo. Potem pracowałam w mniejszym sklepie $\mathrm{z}$ wełną i podobało mi się to. Ale później latem było tam bardzo cicho i nudziłam się na śmierć, wiesz, po prostu ((mm)) siedziałam i nic nie robiłam. Byłam tam tylko ja i kierowniczka, i ona musiała czasem iść do innego sklepu, albo musiała wyjść w porze obiadowej, albo w święto, i zostawiała mnie, żebym sama zajęła się sklepem, i czułam się bardzo samotna, bo nikt nie przychodził ((Tak)). Wiesz, sprzątałam rano i trzeba było cały dzień siedzieć i czekać ((Tak)).

Betty o innych posadach:

BW W biurze była fajna grupa dziewczyn; były takie dwa tygodnie, kiedy było bardzo spokojnie, na koniec tego tygodnia można było się rozluźnić, ale dziewczyny były w porządku i można było z nimi rozmawiać i tak dalej ((Mm)), żeby jakoś zabić czas. Ale były takie dwa tygodnie, które były naprawdę ciężkie, agenci przychodzili z księgami (...). Było tam wiele polis przemysłowych i kiedy przychodzili, trzeba było sprawdzić w aktach, czy dotyczy ich jakaś inna polisa, i odesłać ich do Biura Głównego. Zajmowałam się też wypisywaniem polis, jeśli ktoś chciał wykupić polisę i tak dalej. To było ciekawe.

DH Czy praca wśród przyjaciółek była dla ciebie tak samo ważna jak praca dla samej pracy?

BW O tak. Podobało mi się lubienie tych osób, z którymi pracowałam, bo miałam jedną taką posadę, gdzie byłam tylko trzy tygodnie, a ludzie tam byli okropni. Nie rozmawiali ze mną, patrzyli na mnie dziwnie i nie miałam poczucia, że tam należę; miałam poczucie, że nie powinno mnie tam być. Nie chcieli mnie tam. Więc byłam tam tylko trzy tygodnie, nie lubiłam tej pracy.

Relacje te łączy świadomość, że większość posad była niesatysfakcjonująca i w wielu przypadkach - nudna. W pierwszym fragmencie Anne nie ma złudzeń co do charakteru wykonywanej pracy. Praca w fabryce jest opisana jako „nudna”, a kiedy było „zbyt głośno, żeby rozmawiać”, to znaczy kultura miejsca pracy nie wynagradzała wysiłku, stał się on nie do zniesienia. Jednakże fakt, że Anne odeszła z pracy po pół roku, wyrażony jest prawie jako osobista porażka, potwierdzona śmiechem omówionym we wcześniejszej części niniejszego artykułu. Co istotne, choć Anne postrzega pracę w fabryce jako nudną, chciałaby mimo wszystko do niej wrócić. W innym miejscu wywiadu mówi: „chciałabym wrócić do [jakiejś] fabryki”. Po tym, jak wyraziła niezadowolenie 
z pracy w sklepie, Linda znalazła wreszcie posadę w fabryce, którą lubiła, polegającą na wierceniu i frezowaniu; powiedziała, że praca podobała jej się ze względu na różnorodność, ale ludzie też byli dla niej ważni. W późniejszym miejscu wywiadu powiedziała: „brakuje mi [zarabiania] pieniędzy i brakuje mi chłopaków, z którymi pracowałam, wiesz, gdybym wróciła teraz w to miejsce, nie byłoby tak samo, bo ich już tam nie ma”.

Zdecydowanie najczęściej podawanym powodem, dla którego kobiety lubią swoją pracę, jest towarzystwo innych pracowników, kobiet i mężczyzn, oraz to, że praca dawała możliwość rozmawiania z innymi ludźmi. Betty wyjaśnia, jak samotnie wyglądała praca w sklepie z wełną, kiedy była sama. Posady, które uważała za satysfakcjonujące, to te, gdzie mogła zarówno wykonywać ciekawą i zróżnicowaną pracę, jak i rozmawiać z innymi dziewczynami w biurze. Kiedy nie zaakceptowano jej w grupie w pracy wspomnianej w ostatnim fragmencie, opuściła firmę wyłącznie z tego powodu.

Wszystkie powyższe wypowiedzi uprzywilejowują towarzystwo innych pracowników jako ważny element satysfakcji doświadczanej przez kobiety zaangażowane w płatną pracę. Nie sugeruję, że kobiety pracowały tylko z powodu „towarzystwa” i że ich nastawienie do pracy zarobkowej nie jest instrumentalne. Uważam, że to, co ujawnia skupienie się na aspekcie towarzyskim wcześniejszej pracy, jest w dużym stopniu refleksją na temat ich obecnego odizolowania w porównaniu z ich wcześniejszym życiem, kiedy pracowały. Postrzegają one pracę jako ucieczkę przed izolacją w domu - nieświadomy wyraz braku w ich życiu. To za pomocą pojęcia izolacji próbuję zrozumieć opresję kobiet w pozostałej części tego artykułu.

\section{Izolacja}

Rozdzielenie sfery pracy od sprywatyzowanej sfery domu w kapitalistycznym modelu produkcji oraz przypisanie tych przestrzeni odpowiednio mężczyznom i kobietom oznacza, że kobiety na pewnym etapie głównie znajdują się w domu, wykonując prace domowe i opiekując się dziećmi. To właśnie izolacja kobiet w domu i sprywatyzowana natura wykonywanej przez nie pracy została określona przez część kobiet jako forma opresji.

Industrializacja ma długofalowe konsekwencje: rozdzielenie mężczyzny od intymnych codziennych rutyn życia domowego; finansowa zależność kobiet i dzieci od mężczyzn; odizolowanie pracy domowej i opieki nad dziećmi od innej pracy. Zatem poprzez przypisanie kobietom pracy domowej i opieki nad dziećmi, poprzez nowoczesne definicje roli gospodyni domowej i roli matki, industrializacja oznacza ograniczenie kobiety-gospodyni domowej do [sfery] domu. Ograniczenie to ma charakter bardziej psychologiczny niż fizyczny... (Oakley 1974: 59) 
Oakley postrzega to ograniczenie jako raczej psychologiczne niż fizyczne, jednak doświadczenia kobiet z klasy robotniczej to często rzeczywiste fizyczne ograniczenie $\mathrm{w}$ domu $\mathrm{z}$ dziećmi ${ }^{42}$.

Anne: Powiedziałam mu: musisz mnie nauczyć prowadzić samochód, a potem będę mogła wyjść. Nie przeszkadzałoby mi to wtedy tak bardzo, po prostu tu na górze jedynym kontaktem ze światem zewnętrznym jest radio i telewizja, a z telewizora wiele nie wyciągniesz.

Telewizję i radio ta kobieta postrzega jako jedyny kontakt ze „światem zewnętrznym”, czego - rzecz jasna - doświadcza jako pasywnej relacji ze swojej strony. Telewizja i radio nie są oczywiście jedyną formą relacji, jaką ma ona ze światem. Jest związana z mężem, rodziną i kilkoma przyjaciółkami, ale nie stanowią oni dla niej „świata zewnętrznego”; są oni częścią „świata rodzinnego”. Związek ze światem „zewnętrznym” widzi ona w mediach ${ }^{43}$.

Poniższy fragment pokazuje kolejny przygnębiający obraz izolacji doświadczanej przez młode mężatki. Wypowiadająca się kobieta, Betty, mieszka na dziewiątym piętrze wieżowca składającego się z mieszkań komunalnych; ma dwoje dzieci w wieku pięć i dwa lata, jest mężatką od ośmiu lat. Jej mąż pracuje przez dwa tygodnie na zmianie dziennej i dwa tygodnie na zmianie nocnej na linii produkcyjnej British Leyland. W obecnym mieszkaniu mieszka ona od pięciu lat.

\section{DH Czy znasz wiele osób ze swojego bloku?}

BW Powiem ci, że znam kilka [osób] „na dzień dobry”. Kiedy je widzę, odzywam się do nich ((mm)), odzywam się do niektórych z nich ((mm)), ale nie znam ich na tyle, żeby na przykład zaprosić do domu ((Nie)) albo ich odwiedzić. Mówię im tylko: dzień dobry.

\footnotetext{
${ }^{42}$ Zob. też Gavron (1966): „Podsumowując, można powiedzieć, że chociaż matka z klasy średniej może napotkać psychologiczne trudności dotyczące swojej roli jako jednostki przy pierwszym dziecku, szybko podejmie ona celowy wysiłek, by potwierdzić własne prawa jako jednostki. Matka z klasy robotniczej, która postrzega macierzyństwo jako coś nieuniknionego, jest tak naprawdę mniej przygotowana na związanie dziećmi i w mniejszym stopniu może poradzić sobie z izolacją, która ją czeka”.

${ }^{43}$ Komunikacja masowa w postaci radia i telewizji wyłania się jako ważny aspekt codziennego doświadczenia moich rozmówczyń. O telewizji i radiu nie wspomina się nigdy jako o zajęciach „czasu wolnego” czy wypoczynku; stanowią one integralną część życia codziennego. By użyć radia jako przykładu, kobiety słuchają programu pierwszego radia [BBC] i radia lokalnego w ciągu dnia, zajmując się pracami domowymi. Z komentarzy o roli radia w ich życiu wynika, że kobiety postrzegają prezentera jako dodatkową „osobę” w ich sprywatyzowanym świecie. Programy, do których ludzie dzwonią, są także istotne $\mathrm{w}$ zapobieganiu izolacji. Jedna $\mathrm{z}$ kobiet powiedziała: „Lubię słuchać dzwoniących, lubię rozmowy (...). Myślę, że to dlatego, że jestem sama”. Programy te nie tylko zapewniają kontakt ze światem „zewnętrznym”; wzmacniają także sprywatyzowaną izolację, potwierdzając sytuację obopólności: tysiące innych kobiet znajduje się w tej samej sytuacji, swego rodzaju „izolacji zbiorowej” (Zob. bardziej szczegółowa analiza tego aspektu życia kobiet zawarta w przygotowywanej pracy magisterskiej).
} 
DH Czy masz jakichś innych, hm, przyjaciół?

BW O nie, miałam przyjaciół, kiedy pracowałam, i straciłam kontakt z jedną dziewczyną, z którą pracowałam w Patrick Motors. [Ta dziewczyna] dała mojej mamie swój numer telefonu parę lat temu i miałam do niej zadzwonić, ale nigdy się nie zebrałam, a potem zgubiłam [ten numer].

DH Co robisz w wolnym czasie, jeśli go masz?

BW Nie mam go zbyt wiele tak naprawdę, wiesz, tylko siadam i patrzę, jak mały się bawi ((Tak)). Robię to często, tak naprawdę.

DH Nie masz, hm, zazwyczaj kiedy jesteś sama, tak?

BW Tak, zazwyczaj robię to, jak jestem sama, nie tak, jak w weekendy, kiedy jest tu mój mąż ((Tak)), ale zazwyczaj po prostu siedzę sama. Nieczęsto ktoś tu w ogóle przychodzi, wiesz. ((Nie)) Bardzo rzadko przychodzą. ((Tak))

DH Czy twój mąż często pracuje nocami, czy ...

BW Pracuje nocami przez dwa tygodnie. (...) Kładzie się [wtedy] spać około wpół do dziesiątej [rano] i wstaje około wpół do szóstej [wieczorem].

DH Och, więc naprawdę siedzisz ciągle sama?

BW: Tak, głównie siedzę sama.

DH I pewnie jesteś też sama nocami?

BW Tak, bo [mąż] wychodzi o ósmej, więc jestem sama całą noc, ale przyzwyczaiłam się do tego. Wiesz, na początku bardzo się bałam, jak byłam sama w nocy ((Mm)), ale można się do tego przyzwyczaić. ((Tak)) Nie czułam się tak źle, mieliśmy najpierw kota i czułam się z nim bezpieczna, śmieszne ((Tak)), a potem musieliśmy się go pozbyć, bo sąsiedzi cały czas na niego narzekali ((Mm)) (...) Andrew, cicho, tatuś śpi. Kiedy urodziłam Shane’a, był dla mnie dobrym towarzyszem, wiesz, moje pierwsze dziecko. Wystarczał mi jako towarzystwo, a ja rozmawiałam z nim, odkąd był malutki. ((Tak)) Myślałam, że rozumiał, ale pewnie nie (śmiech), ale był po prostu towarzyszem, kimś, do kogo mogłam mówić (...) Zanim go urodziłam, mówiłam do kota (śmiech) i jestem pewna, że kot mnie rozumiał. (śmiech)

Fragmenty te, choć może ukazują skrajny przykład izolacji pod względem ilości czasu spędzanego samotnie (ponieważ mąż tej kobiety pracuje na nocnej zmianie przez dwa tygodnie z czterech), mimo to trafnie odzwierciedlają odizolowaną egzystencję wielu kobiet ${ }^{44}$. Betty nie zna wielu kobiet w bloku,

\footnotetext{
${ }^{44}$ Liczba pracowników fizycznych zaangażowanych w pracę na zmiany zwiększyła się o więcej niż połowę w dekadzie od 1957 do 1967 i od tego czasu wciąż rośnie (Cliff 1970). Kinnersley (1973) podaje przykłady wpływu pracy zmianowej na pracowników i komentuje zakłócenia w ich życiu rodzinnym i towarzyskim, ale nie wspomina o wpływie pracy zmianowej na żony. Zob. też Young i Willmott (1973, Rozdział 7: „Shiftwork”).
} 
w którym mieszka, i tylko kilka zna „na dzień dobry”. Określenie to sugeruje powierzchowną znajomość z osobami, które czasami widuje się w okolicy; nie wskazuje ono na żadną formę przyjaźni czy prawdziwych kontaktów. To zwrot, który pojawia się we wszystkich moich wywiadach; wiele kobiet mówi, że tak naprawdę kogoś nie „znają”, „znają [go] tylko na dzień dobry”. Jak wiele kobiet po ślubie, Betty straciła kontakt z przyjaciółmi z pracy i szkoły, a zawieranie nowych przyjaźni wydaje się trudne. Ponieważ dziewczęta często mają jedną „najlepszą przyjaciółkę”, nie zawsze posiadają grupę „koleżanek” jak chłopcy i często tracą tę najlepszą przyjaciółkę po zamążpójściu. Nie daję do zrozumienia, że kobiety nigdy nie mają przyjaciół, ale wskazuję po prostu na to, że ilość czasu, jaką niektóre kobiety spędzają z jakimikolwiek innymi osobami, jest minimalna. Kiedy Betty mówi: „zazwyczaj po prostu siedzę sama. Nieczęsto ktoś tu w ogóle przychodzi, wiesz. ((Nie)) Bardzo rzadko przychodzą”, jest to wierne odzwierciedlenie jej sytuacji. Brak kontaktu z innymi ludźmi w połączeniu z prawie nieistniejącym życiem towarzyskim czy też zajęciami w czasie wolnym, w których kobiety mogłyby brać udział poza domem, przedstawiają przygnębiający obraz życia wielu $\mathrm{z}$ nich ${ }^{45}$. Inna kobieta opowiada, jak często wygląda przez okno swojego mieszkania i liczy samochody jadące ulicą dziewięć pięter pod nią - "żeby tylko czymś się zająć”* Liczenie samochodów czy rozmawianie „dla towarzystwa” z kotem ukazuje, że izolacja przypadająca w udziale kobietom jest podstępną formą opresji.

\section{Praca domowa: niekończący się wysiłek bez czasu wolnego}

Żadna grupa nie doświadczyła subiektywnego odizolowania życia prywatnego tak głęboko jak kobiety, uwięzione $w$ sferze rodziny, obwiniane o jej rażace problemy, lub zmuszone do negocjowania przepaści między rodzina a światem pracy płatnej. Jako gospodynie domowe i zwłaszcza jako matki, kobiety znalazły się $w$ centrum współczesnych aspiracji do osobistego szczęścia. Gospodyni domowa była odpowiedzialna za nowo wytonione obszary życia prywatnego - zwłaszcza za dzieciństwo, ale także za seksualność, wyrażanie emocji $i$ sposób konsumpcji $w$ rodzinie. Rodzina nie była dla kobiet schronieniem, była miejscem pracy (Zaretsky 1976: 113)

Umiejscowienie domowej pracy kobiety i reprodukcja podmiotów siły roboczej w obrębie sprywatyzowanej sfery domu oznacza, że dla kobiet nie istnieje ani fizyczne, ani emocjonalne oddzielenie sfery pracy i wypoczynku. Sprywatyzowana natura prac domowych, która czyni konieczną izolację pojedynczej kobiety w domu, jest jednym z najbardziej rozpoznawalnych pól jej opresji. Mężczyzna - płatny pracownik - wraca do prywatnej sfery swojego domu,

\footnotetext{
${ }^{45}$ Ów brak zajęć w czasie wolnym jest także czymś zupełnie odmiennym od życia tych kobiet przed ślubem, kiedy to zwykle wychodziły one w każdy wieczór w tygodniu, zostając w domu tylko po to, by umyć włosy i „zrobić prasowanie”.
} 
żeby „zreprodukować się” do stanu pozwalającego na pracę następnego dnia. Ten czas z dala od pracy można traktować jako porę, kiedy płatny pracownik może odpocząć. Nie istnieje jednak taki czas, w którym równocześnie mogłaby odpoczywać kobieta. Ona pracuje w domu podczas dnia, kiedy mężczyzna jest w pracy, ale kiedy on wraca do domu, kobieta wciąż musi pracować.

DH Uważasz więc, że jest większe rozgraniczenie między pracą mężczyzn a ich czasem wolnym niż w przypadku kobiet.

BW Tak, myślę, że mężczyźni mają więcej czasu wolnego, bo oni muszą wychodzić do swojej pracy i kiedy z niej wracają, są z dala od pracy, więc to, co robią, zależy od nich. W sensie: jeśli nie chcą pomagać żonie, nikt ich do tego nie zmusi, mogą po prostu siedzieć całą noc, jeśli mają na to ochotę, i robić to, co chcą. ((Tak)) A kobiety muszą pracować cały czas i nie wychodzą z pracy o piątej, jeszcze muszą zrobić herbatę i wszystkie inne konieczne rzeczy. Na przykład kiedy któreś z dzieci robi straszny bałagan w pokoju, coś takiego, albo rzuci butelką mleka o podłogę, albo coś wysypie na podłogę, [kobiety] nie mogą powiedzieć: „Och, jest już po piątej, nic nie będę robić, niczego nie zrobię do jutra do dziewiątej rano”. Muszą to posprzątać.

DH Ale dlaczego uważasz, że kobiety mają więcej do robienia niż mężczyźni, dlaczego kobiety nie mogą powiedzieć: „Jest piąta, skończyłam”?

BW No, nikt inny tego [za nie] nie zrobi (śmiech), wiesz, musisz się tym zająć albo zostanie niezrobione, ale myślę, że mężczyzna może mniej lub bardziej zignorować każdy bałagan, przymyka na to oczy, a kobieta musi, no, [u nas] to Shane wyrzuca rzeczy, na przykład czasem po prostu wysypuje cukier na podłogę. I nie mogę siedzieć i na to patrzeć, całą noc bym się tym zamartwiała ((tak)) i muszę wstać, nawet jeśli byłam zdecydowana tego nie robić. Muszę wstać i posprzątać, bo nie mogłabym usiedzieć, gdyby [ten cukier leżał na podłodze], ((tak)), wiesz, nie mogłabym rozluźnić się przez całą noc, dopóki bym tego nie zrobiła. (śmiech)

Ten fragment pokazuje różnicę między życiem roboczym mężczyzn i kobiet. Jak mówi Betty, mężczyźni wychodzą do pracy i zostawiają pracę za sobą, kiedy opuszczają miejsce produkcji. Mężczyźni mogą wybrać, co chcą robić, ponieważ w ciągu ich dnia roboczego jest odrębna pora bez pracy. Kobiety nie mają oficjalnego czasu pracy. Według ostatnich wyliczeń długość tygodnia roboczego dla gospodyń domowych wynosi średnio siedemdziesiąt siedem godzin (Oakley 1974). Kobiety nie są jednak zmuszane do tak długiej pracy: wewnętrzny przymus sprawia, że pracują, nawet gdy czują, że powinny odpoczywać. Ten przymus na pewno wynika częściowo $z$ braku granic i z nieustrukturyzowania pracy domowej: nie ma rozgraniczenia pomiędzy pracą a odpoczynkiem ani żadnego sposobu określenia, ile pracy domowej 
„wystarczy”. W powyższym fragmencie Betty wyraża odczuwany przez siebie przymus. Widzi ona, że nie jest w stanie opanować własnych pragnień. Wydaje się, że kobietom brakuje umiejętności powstrzymania się przed pracą częściowo dlatego, że nie mają one dokąd uciec. Łatwiej jest zostawić nieskończoną pracę, jeśli nie jest się z nią ciągle konfrontowanym, lecz jest to niemal niemożliwe, kiedy widzi się tę pracę i wie się, że na drugi dzień i tak będzie trzeba ją wykonać. Praca domowa to niekończący się wysiłek, nie zaś seria zadań do wykonania; w rezultacie wiele kobiet internalizuje niekończącą się naturę swej pracy. Ta sama kobieta wypowiada się o pracy domowej:

DH Czy jest to dla ciebie monotonne?

BW Tak naprawdę trochę tak, bo to w kółko to samo. ((Tak)) Nie ma żadnego urozmaicenia. Nie ma nic, nad czym można by się pozastanawiać w trakcie, po prostu trzeba sprzątać, jeździć odkurzaczem po podłodze, ścierać kurze, a każdy mógłby to zrobić. Nie wykorzystujesz mózgu, żeby się zastanowić na przykład, jak to robić. ((Nie)) To naprawdę nudne, po prostu.

DH Czy lubisz prace domowe, a jeśli tak, wiesz, dlaczego?

BW Zazwyczaj to zależy od mojego nastroju. Jeśli jestem w dobrym nastroju, nie przeszkadza mi [wykonywanie prac domowych], ale jeśli czuję się trochę zmęczona albo mam dość, nie lubię, bo myślę wtedy: „Robię to i będę to musiała zrobić jutro. A jeśli nie zrobię tego dziś, kto zauważy?”. A potem siadam i myślę: „Nie zrobię tego”. Ale potem patrzę w podłogę i myślę: „Nie mogę siedzieć i na to patrzeć, muszę to zrobić”. Wiesz, a potem mam dosyć robienia tego dzień w dzień, wydaje mi się to bezsensowne, wiesz, nieważne, jak często to robię, muszę to ciągle robić i niczego nie osiągam. ((Tak)) Trochę mam dosyć.

Fragmenty te ujawniają rozpoznanie, że natura pracy domowej jest powtarzalna i kompulsywna. Powtarzalność pracy domowej intensyfikuje przymus, którego kobiety doświadczają, kiedy ją wykonują. Kończąc zadanie, niczego się tak naprawdę nie osiąga, gdyż zadanie trzeba będzie powtórzyć następnego dnia. Jednakże dla kobiet nie ma ucieczki od pracy domowej. Jest wszechobecna, cykliczna i nieskończona.

W następnym fragmencie Anne omawia różnice między pracą zarobkową jej męża a jej pracą w domu.

DH Jak myślisz, czy twój mąż ma łatwiejsze, czy trudniejsze życie niż ty?

AB Łatwiejsze (śmiech), bo może po prostu wyjść z mieszkania rano i o wszystkim zapomnieć. No nie wiem, on wychodzi i zapomina, ale ja nie mogę, jestem tu cały czas. To znaczy, nie jest to prawdziwa praca, ciężka praca, jak się ją rozumie. Myślę, że najbardziej męczy ci umysł. To znaczy, kiedy się pracuje, on zna swoją pracę tak dobrze, że prawie mógłby ją wykony- 
wać z zamkniętymi oczami, może myśleć o innych rzeczach i zupełnie się wyłączyć, ale ja muszę tu siedzieć. To jest trudne w inny sposób, wiesz, o czym mówię, trudno myśleć: „Co zrobię potem?”.

Fizyczna natura pracy domowej nie jest tym, co Anne uważa za trudne. Mówi: „To znaczy, nie jest to prawdziwa praca, ciężka praca, jak się ją rozumie. Myślę, że najbardziej męczy ci umysł”. Trudność polega na tym, że musi sama wykonywać wszystkie zadania w sposób zdyscyplinowany, chociaż sam charakter pracy domowej sprawia, że jest to trudne. Ciężko jest zdyscyplinować się do robienia rzeczy, o których wiesz, że trzeba będzie powtórzyć je jutro. $\mathrm{W}$ rezultacie praca domowa jest tak nudna i monotonna jak praca $\mathrm{w}$ fabryce, jednak w sprywatyzowanej sferze domu kobieta nie ma nikogo, z kim mogłaby porozmawiać, żeby ulżyć nudzie. W tym fragmencie kobieta błędnie określa dom jako miejsce, z którego jej mąż chciałby uciec, mówiąc, że ma on możliwość wyjścia z mieszkania i „zapomnienia o wszystkim”. Jednakże dom jest miejscem, do którego mężczyźni uciekają z miejsca produkcji. De facto, mężczyźni mogą także uciec $\mathbf{z}$ domu do męskich zajęć czasu wolnego. Chociaż moje rozmówczynie nie wychodziły z domu samodzielnie, bez męża, mężowie wychodzili do pubu, na mecze piłki nożnej, z „kumplami” itd., a kobiety akceptowały to, że mężczyźni mają „prawo” tak robić.

Dom staje się zatem miejscem „reprodukcji najbardziej niezbędnego środka produkcji kapitalisty: pracownika” (Marks 1976), jest to także miejsce pracy kobiety. Jednakże kobiety nie mogą uciec z domu. „Kobieta płaci osobiście” (Adamson $i$ in. 1976). To właśnie to połączenie izolacji $w$ domu i niemożliwości ucieczki z miejsca pracy do sprywatyzowanej sfery strukturyzuje opresję, której te kobiety doświadczają w kapitalizmie.

\section{Reprodukcja pokoleniowa}

Rola kobiet w reprodukcji pokoleniowej stanowi zarówno teren ich opresji, jak i przyjemności, której doświadczają w „macierzyństwie”. Jest to często aspekt życia, który kobiety lubią najbardziej, pomimo ograniczeń, które macierzyństwo narzuca ich wolności. Kobiety mogą reprodukować przyszłe pokolenie pracowników, ale to nie w ten sposób doświadczają i internalizują macierzyństwo. To, co określają jako przyjemne, to raczej doświadczenie wychowywania jednostki, uczenia dziecka różnych umiejętności, oczekiwania związane z jego przyszłością. Istnieje zatem wyraźna różnica między reprodukcją krótkoterminową lub codzienną a długoterminową lub pokoleniową. Praca domowa może być nudna, ale zajmowanie się dzieckiem jest bardziej przyjemne. Jednak rola wychowujących dzieci jest dla kobiet terenem sprzeczności. Te, z którymi rozmawiam, często wyrażają ambiwalentne uczucia dotyczące negocjowania tej roli wobec pragnienia powrotu do pracy. 
DH Czy wolałaś pracować [zawodowo] niż zajmować się domem?

AB Tak i nie. To znaczy wolałam pracować, ale nie zrezygnowałabym z niego [dziecka]. Wiesz, co mam na myśli, jeśli miałabym teraz wybrać powrót do pracy i zostawienie go pod czyjąś opieką, wolałabym sama zostać z nim w domu. Więc tak, wolałam pracę, ale nie mogłabym zostawić go z kimś, żeby iść do pracy. Nie jest tak źle.

DH Gdzie widzisz się za następnych kilka lat, czy masz jakieś nadzieje na swoją przyszłość?

AB Chcę mieć więcej dzieci, uporać się z kwestią powiększania rodziny i odchować je, żeby najmłodsze miało pięć lat, było gotowe iść do szkoły, a potem chciałabym znaleźć jakąś pracę, najpierw na część etatu, zanim będę mogła przejść na pełny etat, wiesz, kiedy [dzieci] przyzwyczają się do szkoły, będą wiedziały, co robić i jak przejść przez ulicę... i wiesz, potem uzbierać dość pieniędzy, żeby kupić własny dom.

Anne swoją główną odpowiedzialność wiąże z byciem dla swojego dziecka i w rzeczy samej - dla wszelkich dzieci, które zamierza w przyszłości mieć. Wie, że spoczywająca na niej odpowiedzialność zajmowania się dzieckiem uniemożliwia jej powrót do pracy. Postrzega swoją rolę nie tylko na poziomie codziennej reprodukcji, ale także na poziomie reprodukcji pokoleniowej. Mówi o „kwestii powiększania rodziny” jako o czymś, z czym trzeba się „uporać”. Ma konkretne pojęcie o umiejętnościach, które musi przekazać swoim dzieciom; co uniemożliwia jej rozważanie podjęcia pracy nawet na część etatu, dopóki dzieci nie pójdą do szkoły. Ta sama kobieta mówi o rozziewie między swoim doświadczeniem pracy domowej i opieki nad dziećmi a jego skutkami dla swojej seksualności:

DH Chodzi mi o to, czy sądzisz, że wykonywanie prac domowych i tego rodzaju zakres twojego życia różni się od tego, w którym zajmujesz się dzieckiem?

AB: Tak, różni się.

DH: I czy sądzisz, że istnieje inna ty, taka ty, która chciałaby iść do pracy?

AB: Tak, to znaczy nie siedzę tutaj, karmiąc go i myśląc: „byłoby super pójść do pracy”, wiesz, to taka faza, która trwa może pięć minut, po czym o tym zapominam. Ale kiedy go podnoszę, jestem inną osobą, niż kiedy robię prace domowe. Robię się rozstrojona, kiedy robię prace domowe. Jeśli mąż przychodzi, wiesz, próbuje się ze mną droczyć, [mówię]. . . (śmiech) wiesz, „goń się”, coś takiego. Ale jeśli przychodzi, kiedy zajmuję się dzieckiem, nie przeszkadza mi. Nie mogę tak naprawdę więcej o tym powiedzieć. 
Kobiety często rozpoznają swoją opresję, ale wzbraniają się przed kwestionowaniem jej lub zmierzeniem się z sytuacją, nawet do tego stopnia, że nie pozwalają sobie zaakceptować uczuć, które wskazują na ich opresję. Anne jest świadoma tego, że wykonuje role i zadania, które są niezgodne z tym, jak myśli o sobie, lecz kiedy myśli te przychodzą jej do głowy, zagłusza je. Zdaje sobie sprawę, że praca domowa wpływa na jej nastrój, ale obwinia o to siebie: jest „rozstrojona”. Zdaje sobie sprawę, że praca domowa wpływa na jej seksualność: nie chce seksualnych czy czułych awansów męża, kiedy wykonuje prace domowe, ale akceptuje je, kiedy zajmuje się dzieckiem. Ma poczucie bycia inną osobą, lecz nie pozwala sobie rozważać rozbieżności, w ramach których doświadcza swojego życia. Sheila Rowbotham (1973) opisuje ten aspekt kobiecej świadomości: „Kobiety stworzyły określone sposoby oporu w ramach swojego życia, takiego jakie mają. Są nimi: wyłączanie się, płynne uczucie bycia tylko częściowo tu, tworzenie barier wokół siebie i choroba”.

\section{Wnioski}

W niniejszym artykule próbowałam przyjrzeć się temu, jak na niektóre kobiety z klasy robotniczej wpływa ich „niewidzialny”, choć zasadniczy, wkład w proces akumulacji kapitału. Z konieczności artykuł stanowi bardzo fragmentaryczną relację na temat tego, jak kobiety opowiadają o swoim doświadczeniu życia w sytuacji pełnej sprzeczności. Czasem bardzo trudno jest skomentować dane fragmenty z powodu świadomości, że każdy komentarz może wydać się banalny lub zbyteczny. W wielu przypadkach miałam wrażenie, że słowa wypowiadane przez moje rozmówczynie są silniejsze, kiedy pozostawiam je bez komentarza. Dlatego artykuł zamykam długim fragmentem z rozmowy z jedną z kobiet, który pozostawiam bez szczegółowego objaśnienia, gdyż sądzę, że kobieta ta wyraża własną opresję. Odsłania ona zarazem swoje doświadczenie kobiecości poprzez przejście spod kontroli ojca pod kontrolę męża, jak i zmianę, która zaszła w jej życiu, odkąd ma dzieci. Jej relacja w sposób syntetyczny wyraża to, co chciałam w tym artykule powiedzieć na temat doświadczania życia przez kobiety.

DH Hm, te pytania dotyczą tak naprawdę po prostu ciebie. Czy bycie mężatką i bycie matką wygląda tak, jak się spodziewałaś, a jeśli nie, w jaki sposób się od tego różni?

BW Nie wiem tak naprawdę, bo nigdy o tym tak naprawdę nie myślałam, zanim nie urodziłam dzieci, o byciu matką, o byciu mężatką. Myślę, że wygląda to tak, jak myślałam, bo myślałam: „Masz więcej wolności, kiedy jesteś mężatką, bo możesz robić mniej więcej to, co chcesz, tylko mąż może ci powiedzieć, co masz robić, i możesz się mu mniej lub bardziej sprzeciwić i powiedzieć 'Ej, nie! Jeśli nie chcę tego zrobić, to nie zrobię’. ((Tak)), wiesz, a kiedy twój ojciec mówi ci, co masz zrobić, wtedy raczej to robisz, nie mó- 
wisz: „Nie zrobię tego”, raczej to robisz. (śmiech) ((Tak)). Wiesz, to jest trochę inne, ale jeśli chodzi o dzieci, nigdy tak naprawdę nie myślałam o posiadaniu dzieci, zanim nie urodziłam [synka].

DH Czy twoje życie jest więc takie, jak się spodziewałaś, że będzie z dziećmi i ...?

BW Chyba tak, bo nigdy tak naprawdę dużo o tym nie myślałam, o dzieciach, po prostu myślałam, że dalej będę chodziła do pracy, tak naprawdę.

DH Jak sobie wyobrażałaś, że będzie, zanim miałaś dzieci?

BW Myślałam po prostu, że będzie tak, jak było, kiedy nie byłam w związku, ale będę mężatką, więc będę mogła robić, co będę chciała, wiesz ((Tak)). Po prostu wyjedziemy razem na urlop i tak dalej. Będę robiła mniej więcej to, co chcę robić, zamiast musieć być w domu o konkretnej godzinie każdego wieczoru. ((Mm)) Tak naprawdę nie myślałam nigdy, że będę miała dzieci i będę musiała się nimi zajmować, i przestanę chodzić do pracy. Nigdy nie przyszło mi to do głowy. (śmiech)

DH Gdybym zapytała kim jesteś, to jak, w jaki sposób postrzegasz samą siebie?

BW Nie wiem, jestem po prostu zwykłą gospodynią domową, robię to, co inni ((Tak)). Wiesz, zwyczajne rzeczy.

DH A czy myślisz, czy uważasz, że masz jedną pracę lub wiele prac?

BW Nie myślę o tym dużo. Robię chyba dużo różnych rzeczy, ale nie myślę o tym tak naprawdę, po prostu to robię. ((Tak)) Nie myślę. Zresztą mąż mówi, że nie myślę za dużo. (śmiech) Mówię mu: „Nie mam o czym myśleć!”.

DH Czy, czy zdarzyło ci się, chodzi mi o to, czy robiłaś kiedyś plany i zastanawiałaś się, co będziesz robić?

BW Robiłam tak, zanim wyszłam za mąż. Planowałam wszystko miesiące do przodu. Na przykład ślub był zaplanowany na kilka miesięcy wcześniej ((Mm)), tak samo wszystkie urlopy planowaliśmy dużo do przodu, planowaliśmy Boże Narodzenie. Albo kiedy wychodziliśmy, planowałam na przykład, co założę i czy pójdę do fryzjera ułożyć włosy, i tak dalej. Ale już tak nie robię, nie myślę o niczym, zanim to po prostu nie nadejdzie i wtedy w ostatniej chwili uderza mnie myśl: „O rany, nic nie przygotowałam”, wiesz ((Tak)), i wtedy robi się wielkie zamieszanie. Nie wiem, myślę, że tak jest, odkąd urodziłam dzieci, o niczym już tak naprawdę za bardzo nie myślę.

DH Jak sądzisz, dlaczego się tak zmieniłaś?

BW Nie wiem naprawdę. Mąż mówi, że zmieniłam się okropnie, odkąd urodziłam Shane’a, no wiesz, ale nie myślę o tych rzeczach, [które są] poza do- 
mem. Wszystko, o czym myślę, to niemowlęta i dzieci, i może to, jak prać pieluszki (śmiech) i tym podobne nudne rzeczy . . .

\section{Podziękowania}

Chciałabym podziękować Stuartowi Hallowi za komentarze do pierwotnej wersji niniejszego artykułu; Paulowi Willisowi za dyskusję nad tym artykułem i omówienie metod badawczych, ale zwłaszcza za przykład jego własnej pracy. Dziękuję również pani Lemon z Kliniki Matki i Dziecka; szczególnie dziękuję kobietom, bez współpracy których to badanie nie byłoby możliwe.

Dziękuję wreszcie Charlotte Brunsdon za przyjaźń i wsparcie intelektualne w ostatnim roku, które było bezcenne dla rozwoju mojej pracy.

\section{Klucz do transkrypcji:}

... pauza

( ) komunikat niewerbalny, np. (śmiech)

* informacja pochodzi z notatek wykonanych na miejscu, nie z transkryptu

. . osoba mówiąca przerywa

(( )) komunikat fatyczny, np. ((Mm))

(...) fragment wycięty

\section{Bibliografia}

Adamson O., Brown C., Harrison J., Price J. 1976. Women’s Oppression under Capitalism. Revolutionary Communist, vol. 5.

Althusser L. 1971. Ideology and Ideological State Apparatuses, in: Lenin and Philosophy and Other Essays, New York, London: Monthly Review Press [przekład polski: L. Althusser. Ideologie $i$ aparaty ideologiczne państwa. Przeł. A. Staroń, http://www.filozofia.uw.edu.pl/skfm/publikacje/althusser05.pdf.

Cliff T. 1970. The Employer's Offensive - Productivity Deals and How to Fight Them, London: Pluto Press.

Gavron H. 1966. The Captive Wife: Conflicts of Housebound Mothers. London: Routledge \& Kegan Paul.

Kinnersly P. 1973. The Hazards of Work. London: Pluto Press.

Marks K. 1976. Capital: A Critique of Political Economy. Volume I. New York: Vintage Books [przekład polski: K. Marks, Kapitał, t. 1. Tłum. Nieznany. Warszawa: Książka i Wiedza 1950].

Oakley A. 1974. Sex, Gender and Society. London: Temple Smith.

Rowbotham S. 1973. Woman's Consciousness, Man's Worlds. London: Penguin. 
Young K., Harris O. 1976. The Subordination of Women in Cross Cultural Perspectives. In: Papers on Patriarchy. Brighton: The Women's Publishing Collective.

Young, M. i Willmott, P. 1973. The Symmetrical Family. New York: Pantheon Books.

Zaretsky E. 1976. Capitalism, the Family and Personal Life. New York: Harper and Row.

\begin{abstract}
This article is based on current research into the culture of young working class housewives at home with young children. The research is conducted by tape-recorded interviews in their homes and covers many aspects of women's personal experience both before they were married and in their present situation. The article will concentrate on their present role as housewives and mothers and their understanding of this role in relation to their previous experience as wage labourers. It focuses on the isolation of women within the privatized sphere of the home, and attempts to present isolation as one of the ways which these women experience oppression and to locate the experience within the structures of capitalism. Although it is recognized that there is no simple way of 'reading' accounts of subjective experience, I would hold that they do point to the sites of structural contradictions, however indirectly. I also think, as is argued by Sheila Rowbotham (1973), that women's subjective experience reveals a 'sense of oppression', and this oppression I would see as having a material basis.
\end{abstract}

Keywords: women; isolation; oppression; capitalism; wage labour. 